\section{A PÉNZBŐSÉG NEM FELTÉTLENÜL GENERÁL KIUGRÓ INFLÁCIÓT RÖVID TÁVON INTERJÚ WIEDER GERGŐVEL}

Lambert Gábor (Magyar Biztositók Szövetsége), gabor.lambert@mabisz.hu

\section{ÖSSZEFOGLALÓ}

Wieder Gergő a KPMG szenior menedzsere, a Budapesti Corvinus Egyetemen végzett okleveles közgazdász, a Pénzügyminisztériumnál bejegyzett adószakértő, illetve regisztrált kockázatkezelő. A mesterdiplomája megszerzése óta a pénzügyi, befektetési szektorral foglalkozik. A KPMG pénzügyi szektorral foglalkozó területéhez 2008-ban csatlakozott, 2015 óta a kockázatkezelésre és a területét érintő szabályozásokra fókuszál. Rendszeresen publikál, ad interjút a pénzügyi szektort érintő szabályozási, kockázatkezelési témákban.

\section{SUMMARY}

Gergö Wieder is Senior Manager at KPMG. He is an economist graduated at the Corvinus University of Budapest, a Hungarian tax expert registered by the Ministry of Finance, and a registered risk manager. Since graduation he has been working in the financial and investment services sector. He joined KMPG as a member of the Financial Services business line in 2008, and he has been focusing on risk management and regulatory topics since 2015 . He regularly publishes and gives interviews on regulatory and risk management topics affecting the financial sector.

Kulcsszavak: biztosítás, Covid-19, ESG, világgazdaság Key words: Insurance, Covid-19, ESG, world economics

\section{JEL: E20, G22, H12}

DOI: $10.18530 / B K .2021 .1-2.6$

http://dx.doi.org/10.18530/BK.2021.1-2.6
Több mint egy éve formálja át korábban megszokott életünket a világjárvány, ám ha be is döntötte tavaly a GDP-ket Amerikában és Európában, mégis bizakodóbb a befektetői hangulat a kilábalást illetően, mint az évezred első évtizedének végén. Van ok a bizakodásra?

Annyiban talán igen, hogy a 2009-es, de akár az 1929-es válságnak is az volt a legfőbb jellemzője, hogy nem volt fenntartható az akkori üzleti modell, amin a gazdaság alapult. 1929-ben, amikor a válság előszele már érződött, az akkori jegybankok ahelyett, hogy segítették volna a kilábalást, restrikciót alkalmaztak, csökkentették a pénzmennyiséget, ami tovább mélyítette a krízist. A 2008-as pénzügyi válság az amerikai ingatlanpiaci, subprime válságból fejlődött ki, amikor is újabb és újabb hitelekkel próbálták finanszírozni a korábban felvett hiteleket. A múltbéli tapasztalatokból viszont a jegybankok próbálnak tanulni. Ráadásul most annyiban más a helyzet, mint másfél évtizeddel korábban, hogy egy évvel ezelőtt voltak ugyan a gazdaságban kérdőjelek, de globális szinten egy prosperáló világgazdaságot talált telibe a hirtelen jött külső sokk. Így most az a kérdés, hogy a gazdaság mennyire éli túl a megfelelő vakcinák és gyógyszerek kidolgozásáig. Ha a jegybankok és az államok biztosítani tudnak olyan kedvező ösztönzőket a gazdaságoknak, mint a bérkiegészítés vagy a kedvezményes hitelek, támogatások, amelyekkel ezt az időszakot át tudják vészelni, akkor középtávon különösebb gazdasági visszaesés nélkül meg lehet úszni a dolgot. Ha a védelem megfelelő és kitart, akkor az egészségügyi válsághelyzet nem fordul át pénzügyi válságba. És akkor az optimistább forgatókönyvek szerint jövő év végére már visszakapaszkodnánk a 2019-es GDP-adatokig uniós szinten. Amerikában pedig akár már 4-5 százalékkal meg is haladhatják a 2019-es szintet. Ha viszont nem működnének az oltások megfelelően, akkor nehéz időszaknak néznénk elébe. Akkor az egészségügyi krízis átfordulhat egy tartós pénzügyi válságba, és a múltban már láttuk, hogy akkor az legalább öt-hat év növekedési áldozattal jár, míg rendeződnek a dolgok.

A 2008-as pénzügyi válság egy generális, globális válságba csapott át. Abból, hogy a járványhelyzet különböző mértékben sújtja az egyes térségeket, illetve ágazatokat, következik az is, hogy a kilábalás üteme akár még országokon belül is különböző lehet?

Valóban, azokat a szektorokat, amelyekben a személyes kiszolgálás szerepe nagyon fontos, mint a turizmusban, szállodaiparban, vendéglátásban, valamint a kapcsolódó szolgáltatások (idegenvezetés, fesztiválok, de akár a fodrászat) terén nagyon súlyos helyzet alakult ki. Azokban az országokban pedig, ahol a személyes közreműködést igénylő szolgáltatások aránya magas a GDP-n belül, ott nehezebb a kilábalás. A különböző kutatások azt mutatják, hogy minden egy százalékpontnyi (GDP arányában) ilyen jellegű szolgáltatástöbblettel 0,6 százalékponttal romlott a GDP az adott országban. Miközben az IT és minden olyan szektor cégei, amelyek elősegítik a távollevők közötti kapcsolatépítést, prosperálnak, mint az a bevételeiken és a tőzsdei árfolyamokon is látszik. 
A biztosítókat hová sorolja? Hiszen az ágazat egésze idehaza például a díjbevételek és a nyereségesség tekintetében a nyertesek közé tartozott, de nemzetközi kitekintésben vállalati szinten a besorolás nagyon függ at tól, hogy ki milyen termékkörrel rendelkezik.

Valóban meghatározó a termékkör. Voltak olyan biztosítások, mint a lakásbiztosítások, ahol az otthoni munka következtében bizonyos kártípusok lecsökkentek. Mindenekelött pedig a gépjármü-biztosításokra volt igaz, hogy viszonylag stabil bevétel mellett csökkentek a kárkifizetések, a kgfb vagy a casco, ahol érdemben lecsökkent tavaly a kárhányad, ami pozitív hatással járt eredményoldalon. Az életbiztosítások terén azért ez érdekesebb téma. Az új életbiztosítási szerződések értékesítése korábban jellemzően személyesen történt. Amikor bejött a járvány első hulláma tavaly tavasszal, mindenhol gondot okozott, hogy lehet az értékesítési csatornát úgy módosítani, hogy legyen is személyes kapcsolat, de betartsuk a vonatkozó hatósági előirásokat és az ügyfél igényeit is. Egyre több ügyfél kezdte elvárni, hogy távolról, online formában is meg lehessen kötni a szerződést. Azt látom, nagyon különbözö, hogy az egyes társaságok mennyire vágtak bele az online csatorna használatába.

\section{Egyre több ügyfél kezdte elvárni, hogy távolról, online}

\section{formában is meg lehessen kötni a szerződést.}

Akik ebben előrébb jártak, azok talán könnyebben veszik az akadályokat. Ami a károldalt illeti, azt látjuk, hogy a koronavírus valamennyire megnövelte sajnálatos módon a halálozási adatokat a hosszú távú trendeket illetően, de nem olyan kiugró mértékben, hogy az jelentős hatással legyen a károk alakulására. Már csak azért sem, mert a járvány korábbi hullámainak leginkább kitett idősebb korosztályok biztosítási szempontból kevésbé voltak érintettek. Ami pedig az egészségbiztosításokat illeti, míg Amerikában, ahol az egészségügyi szolgáltatásokat a magánbiztosításokkal fedezik, sokkal nagyobb az érintettség, mint Magyarországon, ahol állami feladatkörben van inkább az egészségügy. Tehát az eredményesség nagyon függ attól, hogy milyen biztosításokról beszélünk

Mint említette, a jegybankok tanultak a korábbi válságokból. Restrikció helyett pénzbőséget teremtettek. Ez most sikeresen müködik?

Attól függ, hol. A 2000-es évek elején hasonló növekedési pályán volt az EU és Amerika. 2001-2007 között átlagosan 2,1 százalékkal nőtt az Unió és 2,5 százalékkal az Egyesült Államok. Viszont utána, a pénzügyi válságra adott eltérő reakciók nyomán 2019-ben az EU GDP-je 12 százalékkal haladta meg a 2007-es értékét, az amerikai pedig 22 százalékkal. A monetáris uniót ugyanis kissé felkészületlenül érte a külső sokk, és sok erőforrást elvett a megoldás. Előjött az a kérdés is, hogy mennyire működőképes a monetáris unió erősebb fiskális kötelékek nélkül. Amerika kedvezőbb helyzetben volt, már csak azért is, mivel a dollár egy globális tartalékvaluta. Sokkal több mindent meg tud tenni egy olyan jegybank, amely ezt a tartalékvalutát kibocsátja. Ez látszik most is, a koronavírus-válság idején. 2020-ban az EU GDP-je végül nyolc százalékkal esett, ami nagyjából a duplája a hasonló amerikai adatnak. A pénzbőséghez egyébként érdekes adalék, hogy tavaly tavasszal is elindultak a határokon átnyúló nagy pénzmozgások, menekültek a fejlődő országokból a külföldi befektetők megtakarításai. Mondjuk, Amerikába vittek vissza forrásokat, de azután gyorsan realizálták, hogy ott meg nem tudják befektetni a pénzüket. Emiatt akkora pénzbőség van, hogy ezek a források nem sokkal később visszatértek, és normalizálódott a helyzet. Ez a 2008-as válság idején messze nem így volt. Ott évekig még nem állt helyre az egyensúly.

$\mathrm{Az}$ Economist foglalkozott nemrégiben a pénzbőségnek és az egyenlötlen kilábalásnak azzal a helyi következményével, hogy Nagy-Britanniában tavaly hatalmas összegek halmozódtak fel, amelyekkel tulajdonosaik egy számukra kedvező pillanatban fel tudják vásárolni a kevésbé tőkeerős, megrendült cégeket. Ez általános tendencia?

Valóban különleges helyzet, hogy míg a korábbi válságok során az Economist szerint átlagosan negyvenmilliárd fonttal csökkent a vállalatok készpénzállománya, addig 2020-ban százhúszmilliárd fonttal nőtt. Ez visszavezethető az eltérő érintettségre. Tehát vannak cégek, amelyeknek a bevétele továbbra is nagyon jó, miközben mások nem rendelkeznek akkora tartalékokkal, hogy ezt a válságot átvészeljék. És ha jó helyen vannak, és jó ügyfélkörrel rendelkeznek, akkor jó felvásárlási célpontnak bizonyulhatnak. Az állami ösztönzők beindulása a másik összetevő, aminek eredményeképpen 2020 a M\&A tranzakciók számát illetően nagyon erős év volt, és nem csak Nagy-Britanniában. A konszolidáció beindulásának az előjeleit már láttuk tavaly Európában. Most a járvány harmadik hullámában kicsit lecsendesültek a dolgok, de nyáron ismét a folyamat felpörgésére számítok. Erre a magyar pénzügyi piacon is látunk már példákat, és várhatóan ugyanez lesz igaz a turizmusban és a szállodaiparban, vendéglátásban is.

\section{A konszolidáció beindulásának az előjeleit már}

\section{láttuk tavaly Európában.}

Vagyis - egy régi terminológiával élve - a nagy hal megeszi a kishalat?

Lehet ez éppenséggel fordítva is, vagy több szereplő összeolvadásával, amikor nagyjából egy súlycsoportban lévő versenyzők adják össze az ügyfélköreiket, a tevékenységüket, mindenesetre a konszolidáció beindulása várható.

Menekülés a pénzromlás elől? Hiszen a szinte korlátlan pénzbőség megnövelte az inflációs várakozásokat.

Az előző válságnál is azok voltak a várakozások, hogy a jelentős pénzbőség inflációt fog generálni a 2010-es évek elején. Azonban azt az érdekes dolgot figyelhettük meg, hogy a többletpénz nem feltétlenül a fogyasztásban csapódott le, hanem olyan elemekben, amelyeket nem tartalmaz az inflációs kosár. Az egyik ilyen a lakhatás. Az inflációs 
kosárnak nem része a lakhatási költség, miközben 2013-hoz képest 2020-ra nagyon sok helyen megkétszereződött, megháromszorozódott az ingatlanok ára. Ugyanez igaz a megtakarításokra is. Azok a többletjövedelmek, amelyek Magyarországon mondjuk az egykulcsos adó bevezetéséből a középosztály és felsőbb osztályok részére jelentősebb megtakarításokat biztosítottak, világszerte felhalmozódtak, hogy azután a részvényárfolyamok elszállásában csapódjanak le. Ahhoz képest, hogy egy koronavírusos válságidőszakban vagyunk, rekordokat dönt az S\&P index Amerikában.

A lufikat pont az szokta nagyra fújni, hogy az emberek sokáig azt gondolják; a határ a csillagos ég...

Ezért is vizsgálja a viselkedési közgazdaságtan, hogy mit gondolnak az emberek. Az infláció olyan tényező, amely öngerjesztő is tud lenni mind a két irányban. Ha például az emberek inflációs várakozásai megnőnek, nagyobb fizetést kérnek, beindul a spirál. De én azt gondolom, hogy jelentősen nem változtak meg azok a fundamentumok - gondolok az adórendszerekre, állami stimulusokra -, amelyek itt Európában rövid távon jelentősen gerjesztenék az infláció megugrását. Ezért én az elkövetkező egy-két évben még nem számítok a pénzromlás elszállására. A nyersanyagárak, mint az olajé is, amelyek jelentősen beépülnek az inflációs kosárba, nem szabadulnak el annyira, hogy nagyobb inflációt generáljanak. Amerikát illetően viszont érdekes lehet az új kormány ösztönzője. Mindenki kap egy meghatározott összeget, ami hathat a kereslet generálásának irányába. Mikroökonómiai szemmel nézve nem mindegy, hogy mekkora az a jövedelem, amelyet az emberek fogyasztásra használhatnak fel, s az sem mindegy, hogy mindez melyik társadalmi csoportban csapódik le. Akiknél a megtakarításokat gyarapítja, ott nem generál többletinflációt. Ahol, mondjuk, az alsóbb társadalmi csoportokban keletkezik egy többletjövedelem, ott elméletileg okozhatna, de vannak speciális helyzetek és eszközök is. Erre volt jó példa, amikor az egyik jelentős régiós bank külföldi vezetője megkérdezte, hogy ha Magyarországon nagyot nő a minimálbér, és reálbér-növekedésről beszélünk, akkor miért nem okoz ez inflációt? És akkor el kellett magyaráznunk, hogy vannak azért hazai specialitások. Gondoljunk csak például az építőipar borítékos fizetéseire: úgyhogy a béremelés egy része számos esetben nem többletjövedelem, ami többletfogyasztást eredményezhet, hanem egyszerűen fehéredés. Ennek következtében a statisztika néha nehezebben értelmezhető, mert nem mindig tükrözi a valós helyzetet.

Akkor tehát ebben a helyzetben az állami pénzeső akár tovább is szórható, mindenfajta veszélyes makrogazdasági következmény nélkül? Hiszen ki törődik ma az államadóssággal és a költségvetési hiánnyal vagy a maastrichti feltételekkel! Ideiglenes kényszerhelyzetben lennénk, amelynek meglehet a böjtje?

Nagyon függ attól, milyen növekedési pályán mozgunk. Ha a befektetők, akik ezeket az adósságokat finanszírozzák, elhiszik, hogy ezek visszafizethetők, akkor az ösztönzők még tudnak működni abból a szempontból, hogy van rájuk forrás. Ezek az expanzív fiskális intézkedések persze az eladósodottság jelentős növekedéséhez vezetnek, Amerikában a legutóbbi csomag 1900 milliárd dollár. Iszonyatos terhekről beszélünk, de amíg hajlandóak finanszírozni az emberek, addig Amerika nem fog csődbe menni. Nehéz választ adni arra, hogy ez meddig mehet, számos kutatás és megannyi Nobel-díjas közgazdász foglalkozik ezzel a témával. Amikor a maastrichti kritériumok kiépültek, és az IMF hitelezett a fejlődő országoknak, akkor szoros költségvetési fegyelmet írtak elö. Ráadásul a várakozások is abból indultak ki, hogy ezek mennyire szükségszerüek, mennyire van mozgástér az adósságok növelésére. $\mathrm{Az}$ utóbbi időben viszont az elemzések azt mutatják, hogy nagyobb a mozgástér, mivel a befektetők, akik a kapcsolódó kötvényeket lejegyzik, kevésbé reagálnak negatívan az államadósságok növekedésére.Én azt gondolom azonban, hogy ez örök időkig nem fog menni. Valószínűleg csak addig, ameddig a gazdasági növekedés tud megfelelő pályán haladni, és azt gondolják a befektetők, hogy a növekedéssel összhangban vannak ezek az adósságnövelések. Az államok pedig két módon tudják leépíteni az adósságukat. Kinőhetik, ami jó megoldás, különösen Amerikában, ahol jobb a helyzet, mint Európában. Kontinensünkön ugyanis különösen a népességszám alakulása aggasztó, ami a hatékonyság mellett a gazdasági növekedésnek egy fontos eleme. Ez kihívásokat jelent. Közép-hosszú távon az inflációt, a másik megoldást ezért sem lehet kizárni, mert ez kiváló fegyvere az országoknak az államadóssággal szemben, mint ahogy az a hetvenes években is történt. De ennek ellenére is azt gondolom, hogy nem az elkövetkező egy-két évben következik be az infláció felpörgetése. Hozamemelkedések ettől függetlenül lehetnek, miként januárban is volt már egy nagyobb, egy majdnem száz bázispontos növekedés a tízéves állampapírhozamokban. A hozamszintek azért még jelenleg eléggé alacsonyan vannak, de a következő évre egy kisebb kamatemelkedés be van már árazva már csak azért is, hogy megfelelő jelzéseket küldjenek a jegybankok, hogy kézben tartják az inflációt.

Az utóbbi időben az elemzések azt mutatják, hogy a befektetők kevésbé reagálnak negatívan az államadósságok növekedésére.

Az, hogy ekkora pénztömeg keresi a megtérülési lehetőségeket, helyzetbe hozhatja a zöld pénzügyek és a fenntartható finanszírozás - legalábbis nálunk - ma még egzotikusnak számító befektetéseit?

A zöld termék kategóriát nem szeretem használni, inkább az ESG-terméket (Environment Social and Governance, környezeti, társadalmi és irányítási), mivel abban nemcsak a környezetvédelem kap súlyozást, hanem több tényező is. A terminológiát illetően az ESG a fenntarthatósággal sem teljesen szinonim, mert az ESG már jobban leszabályozott, mérhető, pontozható fogalomkör, a fenntartható pedig általánosabb 
megfogalmazás. Ezeknek a pénzügyi termékeknek a súlya még valóban alacsony itthon, viszont hosszú távon alapvetően jobb hozamokkal rendelkezhetnek, mint a hagyományos termékek. Az MNB is azért támogatja a zöld kezdeményezéseket, mivel az elgondolás szerint azok a szereplők, akik a hosszú távú környezeti-társadalmi-irányítási kockázatokra odafigyelnek, a napi működéssel is jobban törődnek, tudatosabban irányítják az adott vállalatot, így eredményesebben működnek. De hasonló logika vezethető le a green bondok, a zöld kötvények esetében is. A magyar állam tavaly júniusban bocsátott ki zöld kötvényt, a Növekedési Kötvényprogram keretében ingatlanfejlesztői zöld kötvény is megjelent már. Az már látszik, hogy itt is alacsonyabb csődkockázattal számolnak az érintettek, megjelenik a tudatosabb befektetés. A másik oldalról azok az ingatlanok, amelyeket ennek keretében létrehoznak, környezettudatosabbak, energiahatékonyabbak, így jobban értékesíthetők. Ezért egy esetleges csőd esetében az értékesítésük kisebb kockázattal jár a finanszírozó bank, illetve a kötvényt lejegyzők felé.

\section{Ez az elmélet, de ennyi elegendő a befektetői kedv felcsigázásához?}

Azt mutatják a számok, hogy azoknak a társaságoknak a részvényhozamai, amelyeknek jobb ESG score-jaik, besorolásuk van, kedvezőbbek. A koronavírus időszaka alatt, húsz százalékos blokkokra osztva a cégeket, megnéztük, hogy a legjobb ESG minősítésű amerikai cégek részvényei 3,08 százalékkal teljesítettek jobban, mint a S\&P500 index. A legrosszabb ESG besorolással rendelkezők viszont 7,4 százalékkal estek nagyobbat az indexnél.

\section{Ehhez képest viszont igen lassan épülnek fel a zöld portfóliók.}

Magyarországi kibocsátású és kezelésű befektetési alapok esetében ezen termékekből még valóban kevés van. A BAMOSZ oldalán lehet őket követni. Most is készül egy iránymutatás, hogyan osztályozzák ezeket az alapokat, illetve a Föld Napján, április 22-én megjelenik az MNB zöld ajánlása is, erre vonatkozó javaslatokkal, elvárásokkal (az interjú április elején készült. a szerk.).

\section{A biztosítók megtakarítási típusú termékeiknél előreláthatóan}

\section{elérhetőek lesznek majd ESG-tematikus alapok.}

Az elterjedésük egyrészt értékteremtő is lehet, másrészt vannak ügyfelek, akik külön ezeket keresik. Vagyonkezeléssel foglalkozó barátokkal beszélgetve ők is azt tapasztalják, hogy egyre több ügyfél jelenik meg, akinek konkrét célja ESG-termékek vásárlása. A biztosítók részéről is várható az érdeklődés növekedése, a megtakarítási típusú termékeiknél előreláthatóan elérhetőek lesznek majd ESG-tematikus alapok, amelyek figyelembe veszik a fenntarthatósági tényezőket.
Egy ilyen trendi dolog esetében mi a háttere az óvatos, körültekintő megfogalmazásnak? Éppen a felkapott divatjelleg és a green washing jelentkezése, ami arról szól, hogy el kell választani, ki a zöld és ki nem. Ezt pedig nem mindig könnyű megtenni. Nagyon sok szereplő van a piacon, akik az ESG-score-hoz hasonló értékeket számolnak, ám az a nagy kérdés, hogy mennyire megbízhatóak ezek az adatok, illetve hogy melyik cégnél állnak egyáltalán rendelkezésre. Például a S\&P 500 cégeinek hatvanhét százaléka adott ki 2020-ban a 2019-es évre vonatkozó fenntarthatósági jelentést. Az Eurostoxx 600 európai cégeknél ez már 79 százalék, viszont az ázsiai régióban bőven ötven százalék alatt van, vagyis a fenntarthatósági jelentéseket még a tôzsdei cégek esetében sem mindig adják ki.

\section{Ezek ugye, még nem kérhetők úgy számon, mint a mérlegadatok?}

Nem, és éppen az a másik nagy kérdés, hogy a jelentések mennyire megbízhatóak. Azt mondanám, hogy a folyamat még nem kellően standardizált, és nem is mindig történik meg ennek az objektív felülvizsgálata. Vannak cégek, amelyek igénybe vesznek erre, mondjuk külső szolgáltatót, amelyek tanúsítják, hogy a fenntarthatósági jelentés megfelelö, de ez nem általános még. Azt gondolom azonban, hogy a jövő majd ebbe az irányba fog elmozdulni. Az amerikai felügyelet is egyre inkább azt látja, hogy a befektetők szempontjából egyre fontosabb információ a fenntarthatóság, az, hogy ESG szempontból mennyire jó egy cég. Mivel ezek fontos befektetési adatoknak minősülnek, oda kell figyelni arra, hogy hitelesek legyenek, hangsúlyozza az amerikai felügyelet. A könyvvizsgálatok, a pénzügyi számok auditálása is így indult sok-sokévvel ezelőtt. Hasonlóképpen a tőzsdei cégek előbb-utóbb számolhatnak azzal, hogy a szabályozók valamilyen független vizsgálatot el fognak várni a fenntarthatósági jelentésekhez is. 